\title{
Bumblebee Honey in the Nordic Countries
}

Ingvar Svanberg ${ }^{1}$ and Åsa Berggren ${ }^{2}$

${ }^{1}$ Institute for Russian and Eurasian Studies, Uppsala University, Uppsala, Sweden. ${ }^{2}$ Department of Ecology, Swedish University of Agricultural Sciences, Uppsala, Sweden.

ingvar.svanberg@ires.uu.se

\begin{abstract}
Research in historical ethnobiology can provide information about little known and seemingly insignificant practices in the past. The utilization of insect products as a foodstuff is a rare custom in Europe and data on this practice are scarce. From Nordic countries, we have information about producing ant schnapps with the help of the red wood ant, Formica rufa L., which has been used both as a remedy and as a drink. Honey and beeswax were once gathered in the forests from wild honey bee colonies, but have been replaced with products from the domestic honey bee, Apis mellifera $\mathrm{L}$. Another product, once a well-known and appreciated sweet, especially among children, was nectar gathered from bumblebee nests. Collecting the nectar from bumblebee nests is an activity that has been practiced within living memory in many parts of the Nordic countries. This seems to be an ancient practice dating back at least a millennium that has survived until recently. It is an example of how methods and sources established within historical ethnobiology can be used to gain knowledge on the past as well as possible future uses of available biological resources.
\end{abstract}

Received August 20, 2018

OPENӘACCESS

Accepted October 20, 2018

DOI 10.14237/ebl.9.2.2018.1383

Keywords Foraging, Insect products, Historical ethnobiology, Wild foods, Entomophagy

Copyright (c) 2018 by the author(s) licensee Society of Ethnobiology. This is an open-access article distributed under the terms of the Creative Commons Attribution-NonCommercial 4.0 International Public License (https://creativecommons.org/licenses/by-nc/4.0), which permits non-commercial use, distribution, and reproduction in any medium, provided the original author and source are credited.

\section{Introduction}

Cultural habits and local knowledge are changing fast, and many traditions and foraging activities that interest ethnobiological research are losing ground. There are, for instance, very few data documented about traditional food habits that include insects and insect products in Europe. Israeli zoologist Shimon Fritz Bodenheimer (1951) mentions in his now-classic review of human entomophagy that cockchafers, Melolontha spp., were eaten by children or used as famine food in certain areas of Italy and Ireland. Grasshoppers were eaten in Russia as well as by the Tatars of Crimea in the nineteenth century. Adult scarab beetles, Amphimallon pini (Olivier 1789), were eaten by people in Wallachia and Moldavia, while peasants in Lombardy ate the Amphimallon assimile (Herbst 1790).

Fascinating habits can be discovered through historical documents. In Sweden, we can read in the written folklife records kept in the ethnographic and folklore archives about interesting products that were traditionally gathered and still are, to some extent. Formic acid-produced from red wood ants, Formica rufa L.- has been used to flavor "ant schnapps" (myrbrännvin), i.e., spirits flavored with formic acid. It has a long tradition both as a remedy and as an appreciated flavored liqueur; it is occasionally still made (Linder 2001).

Although the peasantry in Nordic countries has usually appreciated bumblebees, these taxa have played a minor role in folk biology. However, we have a record that a mixture was made in a bottle of salt along with the first bumblebee sighted in spring. This bumblebee salt was then given to cattle before they ate the first fresh grass in summer. This was believed to make them return from grazing in the forest to the farm at the end of the day (Odstedt 2004).

Recent ethnobiological investigations have revealed that children are still eating the sweet ingluvies (the crop) from day-flying moths of the genus Zygaena and its mimic, the nine-spotted moth, Amata phegea L., in Carnia in northeastern Italy (Zagrobelny et al. 2009). Hungarians in central Europe have consumed the honey stomachs of blackcolored carpenter bees, Xylocopa violacea $\mathrm{L}$. and $X$. valga Gerstäcker (Ulicsni et al. 2016). Harvesting of honey 
and wax from wild or feral honey bee colonies is known from many parts of Europe, including Scandinavia, but is now probably a nearly extinct practice. The western honey bee, Apis mellifera L., is the only species of honey bee native to Europe. Its colonies have been harvested since antiquity (Bodenheimer 1951; Crane 1999; Kohl and Rutschmann 2018; Sandklef 1946). Apiculture in the Nordic and neighboring countries has relied for centuries on the domestic honey bee for honey and wax production as well as for pollination (Sandklef 1946; Van Engelsdorp and Meixner 2010; Williams et al. 1995).

The custom of children sucking the sweet crops of bumblebees seems to be widespread in Europe, according to Bodenheimer (1951). An insignificant but interesting product is "bumblebee honey", the nectar that the bumblebees store in their nests, which has been collected by children in Denmark, Finland, Iceland, Norway, and Sweden. This nectar was an important sweet substance before apiculture was introduced with the arrival of Christianity in the Nordic countries (Bernström 1972; Svanberg 2006b).

\section{Aim and Methods}

Records of human interactions with invertebrates exist, but research in the field in the Nordic countries is rare. The data found in archives and in scattered notes in older literature are invaluable sources when it comes to mapping the diversity of the pre-industrial peasantry's relationship to the biota in the eighteenth and nineteenth centuries (Svanberg 2006a, 2006b, $2007,2008,2017,2018)$. This study is focused on the hunt for and use of bumblebee honey; its approach is ethnobiological (Anderson 2011). Understanding the emic folk view of insects, including their naming, classification, and use, is an ultimate goal of an ethnobiologist (Posey 1986).

Research in historical ethnobiology can provide us with information about little-known and seemingly insignificant practices in the past (Medeiros 2016). Although there are elderly individuals in Sweden who still remember gathering bumblebee honey, it is not a custom that has survived. When we search for information about robbing bumblebee nests, we have to use historical sources. There are several kinds of sources: dialect word collections, folk life records, topographic literature (including travelogues), and zoological literature (Nilsson 2008; Svanberg 2006a, 2006b). With the help of ethnographic records in printed sources, dictionaries, and records in the ethnographic and folklore archives in Sweden (located in Härnösand, Lund, and Uppsala), this article sets out to review and analyze the gathering of nectar from bumblebee nests in the Nordic countries. Questions we aim to answer include: In which areas did this practice exist? Who was gathering the nectar, and when did it take place? The interaction between bumblebees and humans is a biocultural domain that has been little studied to date. Our study will contribute to ethnobiological understandings of how populations use wild insects as food and medicine.

\section{Bumblebees, Honey, and Nests}

There are about 250 species of bumblebees described in the world and most are found in the cooler parts of the northern hemisphere (Falk 2015). The nests of bumblebees are built in various places, such as tree trunks, tussocks, and holes in the ground. A fertilized over-wintered queen usually builds her nest in early spring. Nest sizes differ among species, where the heath bumblebee (Bombus jonellus Kirkby) has small nests (50 workers), and the red-tailed bumblebee ( $B$. lapidarius L.) and the buff-tailed bumblebee (B. terrestris L.) have fairly big nests (several hundred workers) (Cederberg 2012; Falk 2015). The queen and later the workers forage for nectar and pollen, which they bring home to the nest as food for larvae. "Bumblebee honey" or "bumblebee mead" have been the common folk names in the Nordic languages for this nectar. However, these folk names refer to stored nectar, which is not the same type of honey as that from honey bees. In some species, the collected nectar is stored in small honey pots made of wax. In the pots, the nectar becomes more concentrated due to evaporation.

Bumblebees have been found to be able to use their sense of smell and taste to examine the components of and nutrients in their food (Ruedenauer et al. 2015). The bumblebees are therefore able to use the honey stored in the pots for information on the current availability of nectar sources (Dornhaus and Chittka 2005). Nectar gathered from some plants may contain toxic compounds (Adler 2000). Studies have shown a variation in aversion behavior to toxic compounds among species, where bumblebees show less discriminatory behavior (Tiedeken et al. 2014). Humans can also be negatively affected by toxic compounds in the honey they consume (Jansen et al. 2012). Still unknown is whether toxic composites are present in bumblebee honey. If they are, other 
questions arise such as how commonly they occur and whether their presence has affected people's practice of gathering bumblebee honey.

Knowledge about where the different bumblebee species usually placed their nests would have been useful for human hunters. Traditional knowledge on where to find the nests could have incorporated weather variations between seasons that would affect the suitability of different localities for the bumblebees. The data show that there existed a folk taxonomy of bumblebees and also local ideas and uses for bumblebee products (Brøndegaard 1985; Svanberg 2006b).

\section{Denmark}

About 29 species of bumblebees are known in Denmark (GBIF 2018). Danish ethnobotanist Vagn J. Brøndegaard has compiled data from Denmark on the harvesting and use of nectar from bumblebee nests. The honey was usually harvested from the bufftailed and red-tailed bumblebee. The practice seems to have been especially common on Jutland. When young herdsmen were walking in the shrub landscape they searched for bumblebee nests and sometimes they gathered enough honey to bring back home.

One record from Western Jutland in the 1870s describes a haymaker finding a bumblebee nest in the meadow. He used a stick to remove the moss-roof from the nest. The cells were taken out. Those with larvae were put back in the nest, while those filled with bumblebee honey were harvested. After sucking out the honey, the empty cells were returned to the nest. Finally, the moss-roof was returned to its original location. Some nests were very rich in honey and sizable pieces could be brought back home to the farm and eaten with the early morning porridge (davregrod). It was sometimes eaten in buckwheat porridge as a dessert after a supper. From other areas in Denmark, there are records that bumblebee honey was used in courtship. Young lads offered the honey to girls as a romantic gesture, according to records from the Skive area on Jutland in the late nineteenth century. Children sometimes sucked honey straight from the nests with the help of a drinking straw made of grass. In the very dry summer of 1868, the nests contained a lot of honey, which was harvested by farmers in central Denmark (Brøndegaard 1985).

\section{Finland and Estonia}

In Finland and Estonia, about 38 and 19 species of bumblebees, respectively, are recorded (GBIF 2018).
There are notes about the gathering and knowledge of "bumblebee honey" (bomolhonong) from the nowvanished Swedish-speaking areas along the Estonian coastal areas, but the records are few (Danell 1951). Bumblebee honey was also known as "bumblebee mead" (bumlemjöd) in the Swedish-speaking areas of Finland (Ahlbäck 1992). There is also evidence that the ethnic Estonians and the ethnic Finns hunted honey in bumblebee nests (Linnus 1939).

\section{Iceland}

Iceland has about four species of bumblebees (GBIF 2018). A native species is the heath bumblebee, which has probably been in Iceland since the end of the last Ice Age. Harvesting of nectar from bumblebee nests is mentioned in eighteenth century sources. Both Egil Olufsen in his travelogue and natural historian Nicolai Mohr have passages about locals robbing honey from the bumblebee nests (Olafsen and Povelsen 1772). According to Mohr, bumblebees were common in the northern part of Iceland, and the honey was gathered by inhabitants and used as a remedy for all kinds of diseases (Mohr 1786). We have not been able to find any recent information on the use of bumblebee honey.

\section{Norway}

There are about 36 bumblebee species in contemporary Norway (GBIF 2018). The Norwegian peasants in Hadeland in the southeastern part of the country used to call the nectar found in the nests of the buff-tailed bumblebee "honey mead" (bumlemjod) and the small stores or honey pots were known as "honey mead barrels" (bumlemjodtonder) (Hammer 1797:181).

\section{Sweden}

There are about 40 species of bumblebees known in Sweden (Cederberg 2012). In the traditional taxonomy, the peasants differentiated between two to four kinds of bumblebees. They believed that the bumblebee nest was ruled by a "bumblebee king" (bumlekonung). In the folk biology, animal societies reflected the hierarchies that existed in human society. Sources from around $1600 \mathrm{CE}$ already mention this hierarchy of the bumblebee society (Svanberg 2006b).

The Swedish poet Frans Michael Franzén (17721847) refers in the 1820 s to a proverbial expression "also in bumblebee nests there is some honey" (Svanberg 2006b). Folk data about 
"bumblebee honey", also known as "bumblebee mead" (hommelmjö) in some dialects, are found in folk life records and dialect word lists in several provinces of northern Sweden: Hälsingland, Jämtland, Medelpad, Ångermanland, and Västerbotten (Rietz 1867; Wennberg 1873; Nordlander 1933; Nilsson 2008).

Bumblebee honey has been gathered in various parts of Sweden. There is one record from Örkelljunga in Skåne that bumblebee honey has been gathered there (Lund: LUF 10 127). In addition, the South Sami in Västerbotten know about bumblebee honey (Sjulsson 1979). It seems to have been commonly used as a sweet for children. Responses on a questionnaire sent out in the late 1920s from the folklore archive in Uppsala (IFOS) indicated that the bumblebee honey was eaten on the spot or gathered by children to spread on bread (Anonymous 1928). It was known as "bumblebee honey", bumlehonung (Dalsland: ULMA 10467; Småland: ULMA 2534, ULMA 5736, ULMA 5077, ULMA 2203:7, ULMA 2879:24, ULMA 2856:3, ULMA 12 734, ULMA 24 656; Södermanland: ULMA 3287; Uppland: ULMA 2639:1; Värmland: ULMA 3147, ULMA 22 936, ULMA 2859:11, ULMA 2148:4; Västergötland: ULMA 2264:5, ULMA 6072, ULMA 1653; Västmanland: ULMA 4512), "bumble mead", bumlemjöd (Jämtland: ULMA 3619), "bumblebee sweet”, bumlesöta (Hälsingland: Rietz 1867; Wennberg 1873), "bumblebee goodies", bumlegott (Gotland: ULMA 4031; Gustavson 1940), and "mossmice honey" messmösshonung (Västmanland: ULMA 2056).

Some reported that bumblebee honey had a sweeter taste than honey bee honey and especially children preferred it if they could get hold of it. Usually children found bumblebee nests during haymaking. From Ransäter in Värmland, Professor Gösta Bergman recalled from his childhood in 1905 that they used to suck out the honey from the nest with the help of a straw (IFOS: ULMA 3146:2).

There are also some data of the use of bumblebee honey as a folk remedy. There is a record from Frostviken in the province of Jämtland that ear pain (otitis media) was cured with the help of bumblebee honey that was put in the ear (Tillhagen 1958). A record from Dorotea parish in Västerbotten in 1917 reports that bumblebee mead (hommelmjön) was mixed with liquor in a bottle and used to clean wounds (Murberget: LMV-M1302a). This practice is also known from the province of Angermanland at the end of the nineteenth century (Modin 1886).

\section{Other Countries in Europe}

Eva Crane (1999) suggests that the practice of hunting bumblebee nests for honey was quite widespread among subsistence farmers in Europe. Ethnologist and ethnobiologist Béla Gunda (1968) gives several examples from the Carpathian area and Hungary. In Western Transdanubia, bumblebee honey was harvested using a digging stick (Gunda 1968; cf. Gunda 1949). In some villages in Transylvania, peasants lured bumblebees to nest in artificial cylindric "bumble houses" made of earthenware. These were kept in villages and peasants harvested the honey from time to time (Gunda 1968). Irish children also hunted bumblebee nests in connection with haymaking (Crane 1999). As William Shakespeare reminds us, individual bumblebees could be caught for the contents of their honey-sacks. In his play, A Midsummer-Night's Dream (Act 4, Scene 1), we read: "Monsieur Cobweb; good monsieur, get your weapons in your hand, and kill me a red-hipped humble-bee on the top of a thistle; and, good monsieur, bring me the honey-bag" (Shakespeare 1874). Crane (1999) suggests that the lines probably refer to the red-tailed bumblebee.

In 1912 the dedicated apiculturist and entomologist Frederick William Lambert Sladen published a small book about how to keep bumblebees (which he calls humble-bees) in captivity, in specially made nests adapted to fit their behavior. He concludes that under favorable conditions bumblebees store honey, "the flavour of which, as most schoolboys know, is excellent" (Sladen 1912:6). Unfortunately, each nest produces very small amounts. Quite a few bumblebee colonies would be needed to be able to harvest honey in any quantity (Sladen 1912).

In Old Moravia, there was a folk saying connected with bumblebee honey: if you take the honey from the bumblebees in the field, without anyone seeing it, and bring it to the altar, you will find a rich treasure (Grohmann 1864). Bumblebee honey was also used in various folk religious customs in Germany and France (Riegler 1932).

From outside of Europe, we have records of children harvesting honey from bumblebee nests in Japan and rural North America (Ransome 1937). 


\section{Effect on Bumblebees from Harvesting}

There are no studies available on the effect of harvesting honey from bumblebee nests on the bumblebees themselves. However, it is possible that removing stored nectar can have a serious impact on the bees, especially their ability to raise larvae. Nonhuman mammals and birds, as well as other insects, predate nests. To reduce the success of intruders, the bumblebees defend their nest by attacking and stinging the robbers (Cederberg 2012). The honey is not only used as food for both adult bumblebees and larvae, but provides the energy that enables them to keep the colony around the $30^{\circ} \mathrm{C}\left(86^{\circ} \mathrm{F}\right)$ temperature required for brood development (Cartar and Dill 1991). Previous findings have shown that colonies that run out of honey cannot keep the brood warm, and also that their behavior towards intruders changes. Bumblebees low on energy and faced with intruders large (e.g., mammals) or small (e.g., parasites) do not attack to the same degree (Cartar and Dill 1991). A colony with depleted resources could therefore be more vulnerable to predators.

\section{Conclusion}

It is easy to forget that before sugar became readily available in the market, sweet substances were rare among the peasantry in Nordic countries. Sugar was still a luxury in rural areas in the nineteenth century (Nelson and Svanberg 1993; Svanberg et al. 2012). Bee keeping existed in some areas, but many people did not have access to honey and honey products (Sandklef 1946). Gathering activities (as opposed to fishing, fowling [including egg harvesting], and hunting) for wild food were rather limited among the pre-industrial peasants of Nordic countries (Erixon 1951). However, children are fond of sweets and it seems to have been a widespread practice in northern Europe to suck nectar from flowers (Klintberg 2012; Luczaj 2012). It seems that many practices connected with utilizing insects as a food source are connected with children's traditional knowledge of the biota (Anderson 2000; Svanberg 2001). It is easy to understand that the bumblebee nectar stored in the nests offered a pleasant treat for any finder, young or old. As several sources say, the appreciation was so large that people actively searched for the nests.

Because bumblebees, unlike honey bees, have annual rather than perennial colonies, they do not store large amounts of honey. Thus, bumblebee honey is unlikely to become or be developed into a commercially viable product. Several species of bumblebees are declining because of current land use with low availability of flowering plants and heavy use of pesticides (Falk 2015). For some of these species, pressure from honey harvesting could be negative.

As far as we know, bumblebee honey is not harvested any more in the Nordic countries. Nevertheless, the word itself has new life. This is thanks to the popular Swedish author Torgny Lindgren (1938-2017), whose books are translated into many languages. The Västerbotten dialect word for bumblebee honey is the title of his famous novel Hummelhonung (1995) (English translation Sweetness, German translation Hommelhonig), making the word well known among modern readers.

\section{Declarations}

Permissions: None declared

Sources of funding: None declared

Conflict of Interest: None declared.

\section{References Cited}

Adler, L. S. 2000. The Ecological Significance of

Toxic Nectar. Oikos 91:409-420. DOI:10.1034/

j.1600-0706.2000.910301.x

Ahlbäck, O. 1992. Ordbok över Finlands Svenske Folkmål

2. Forskningscentralen för de Inhemska Språken, Helsinki.

Anderson, E. N. 2011. Ethnobiology: Overview of a Growing Field. In Ethnobiology, edited by E.N. Anderson, K. Adams, D. Pearsall, E. Hunn and N. J. Turner, pp. 1-14. Wiley-Blackwell, Hoboken NJ.

Anderson, M. 2000. Saami Children and Traditional Knowledge. In Ecological Knowledge in the North: Studies in Ethnobiology, edited by I. Svanberg and H. Tunón, pp. 55-65. Swedish Biodiversity Centre, Uppsala, Sweden.

Anonymous. 1928. Landsmålsarkivets Frågelistor 14. Bin och Biskötsel. Almqvist \& Wiksell, Uppsala, Sweden.

Bernström, J. 1972. Steklar. In Kulturbistoriskt Lexikon för Nordisk Medeltid 17, pp. 131-142. Allhem, Malmö, Sweden.

Bodenheimer, F. S. 1951. Insects as Human Food: $A$ Chapter of the Ecology of Man. Springer, Leiden.

Brøndegaard, V. J. 1985. Folk og Fauna: Dansk Etnozoology 1. Rosenkilde og Bagger, Copenhagen, Denmark.

Cartar, R. V., and L. M. Dill. 1991. Costs of Energy Shortfall for Bumblebee Colonies: Predation, Social Parasitism, and Brood Development. The Canadian 
Entomologist 123:283-293. DOI:10.4030/

Ent123283-2.

Cederberg, B. 2012. Humlor i Sverige: 40 Arter att älska och Förundras över. Bonnier Fakta, Stockholm, Sweden.

Crane, E. 1972. Bumble Bee Honeys and Others. Bee World 53:38-39.

Crane, E. 1999. The World History of Beekeeping and Honey Hunting. Routledge, London, UK.

Danell, G. 1951. Estlandssvenskarnas Folkliga Kultur 2. Ordbok över Nuckömålet. Lundequistska, Uppsala, Sweden.

Dornhaus, A., and L. Chittka. 2005. Bumble Bees (Bombus terrestris) Store Both Food and Information in Honeypots. Behavioral Ecology 16:661-666. DOI:10.1093/beheco/ari040.

Erixon, S. 1951. Surviving Primitive Gathering in the Nordic Countries. Folk-Liv. Acta ethnologica Europaea 14-15:95-102.

Falk, S. 2015. Field Guide to the Bees of Great Britain and Ireland. Bloomsbury Publishing Plc, London, UK.

GBIF 2018. GBIF Home Page [web page]. https:// www.gbif.org. Accessed on 17 July, 2018.

Grohmann, J. V. 1864. Aberglauben und Gebräuche aus Böhmen und Mähren 1. J.G. Calve, Prague.

Gunda, B. 1949. Plant Gathering in the Economic Life of Eurasia. Southwestern Journal of Anthropology 5:369-378.

Gunda, B. 1968. Bee-Hunting in the Carpathian Area. Acta Ethnographica Hungarica 17:1-62.

Gustavson, H. 1940. Gotländsk Ordbok 2. Lundequistska Bokhandeln, Uppsala, Sweden.

Hammer, C. B. 1797. Fortsættelse af SogneBeskrivelse over Hadeland udi Aggershuus Stift udi Norge. Topographisk Journal for Norge 21:111-192.

IFOS: Institute for Language and Folklore, Uppsala, Sweden. Nd. Folklife Records (ULMA): Document ULMA 1653, ULMA 2056, ULMA 2148:4, ULMA 2203:7, ULMA 2264:5, ULMA 2534, ULMA 2639:1, ULMA 2856:3, ULMA 2859:11, ULMA 2879:24, ULMA 3146:2, ULMA 3147, ULMA 3287 , ULMA 3619, ULMA 4031, ULMA 4512, ULMA 5736, ULMA 5077, ULMA 6072, ULMA 10467, ULMA 12734, ULMA 22936, ULMA 24656.

Jansen, S. A., I. Kleerekooper, Z. L. M. Hofman, I. F. O. M. Kappen, A. Stary-Weinzinger, and M. A. G. van der Hayden. 2012. Grayanotoxin Poisoning:
"Mad Honey Disease" and Beyond. Cardiovasc

Toxicol 12:208-215. DOI:10.1007/s12012-012-9162-

2.

Klintberg, B. 2012. Barnlekar i Växtriket. Rig 95:155168.

Kohl, P. L., and B. Rutschmann. 2018. The Neglected Bee Trees: European Beech Forests as a Home for Feral Honey Bee Colonies. PeerJ. 6:e4602.

DOI:10.7717/peerj.4602.

Linder, J. 2001. Myrsup. Dagens Nyheter. August 18, 2001:8.

Lindgren, T. 1995. Hummelhonung. Nordstedt, Stockholm.

Linnus, F. 1940. Eesti Vanem Mesindus 1. Metsamesindus. Eesti Rahva Muuseum, Tartu.

Luczaj, Ł. 2012. Ethnobotanical Review of Wild Edible Plants of Slovakia. Acta Societatis Botanicorum Poloniae 81:245-255. DOI:10.5586/asbp.2012.030.

Lund. Nd. Folklife Archive, Lund University, Sweden: Folklife Records (LUF): Manuscript LUF 10127.

Medeiros, M. F. T. 2016. Historical Ethnobiology. In Introduction to Ethnobiology, edited by

U.P. Albuquerque, R. Romeu, and N. Alves, pp. 19-24. Springer International Publishing, New York, NY.

Modin, E. 1886. Huskurer ock Signerier samt Folkliga Namn på Läkemedel från Angermanland. Norstedt, Stockholm, Sweden.

Mohr, N. 1786. Forsog til en Islandsk Naturbistorie, med Adskillige Oekonomiske samt Andre Anmarkninge. Christian Friderik Holm, Copenhagen, Denmark.

Murberget, Västernorrland County Museum, Härnösand, Sweden: Levi Johansson Collection of Folklore (LMV-M): Manuscript LMV-M1302a.

Nelson, M. C., and I. Svanberg. 1993. Coffee in Sweden: A Question of Morality, Health and Economy. Food and Food Ways 5:239-254. DOI:10.1080/07409710.1993.9962006.

Nilsson, A. N. 2008. Dialektala namn på Insekter och Andra Småkryp i Norrland. Natur i Norr 27:1-12.

Nordlander, J. 1933. Ordbok över Multråmålet. C.E. Fritzes, Stockholm, Sweden.

Odstedt, E. 2004. Norrländsk Folktradition. Kungl. Gustav Adolfs Akademien för Svensk Folkkultur, Uppsala, Sweden.

Olafsen, E., and B. Povelsen. 1772. Reise Igiennem Island 1. Jonas Lindgrens Enke, Sorøe, Sweden. 
Posey, D. A. 1986. Topics and Issues in Ethnoentomology with Some Suggestions for the Development of Hypothesis-Generation and Testing in Ethnobiology. Journal of Ethnobiology 6:99120.

Ransome, H. M. 1937. The Sacred Bee in Ancient Times and Folklore. G. Allen \& Unwin, London, UK.

Riegler, R. 1932. Hummel. In Handwörterbuch des Deutschen Aberglaubens 4, edited by E. HoffmanKrayer, pp. 467-470. Walter de Gruyer, Berlin, Germany.

Rietz, J. E. 1867. Svenskt Dialekt-Lexikon 2. B. A. Cronholm, Malmö, Sweden.

Ruedenauer, F. A., J. Spaethe, and S. D. Leonhardt. 2015. How to Know Which Food is Good for You: Bumblebees Use Taste to Discriminate between Different Concentrations of Food Differing in Nutrient Content. The Journal of Experimental Biology 218:2233-2240. DOI:10.1242/jeb.118554.

Sandklef, A. 1946. Svensk Biskötsel före 1850. Lantbruksförbundets Tidskrifts AB, Stockholm, Sweden.

Shakespeare, W. 1874. A Midsummer-Night's Dream. D. Appleton \& Co., New York, NY.

Sjulsson, K. 1979. Kristoffer Sjulssons Minnen: Om Vapstenlapparna i Början af 1800-Talet. Nordiska Museet, Stockholm, Sweden.

Sladen, F. W. L. 1912. The Humble-Bee, Its Life-History, and How to Domesticate It, With Description of All British Species of Bombus and Psithyrus. McMillan and Co., London, UK.

Svanberg, I. 2001. Barkbåtar och Vasspipor. In Människan och Naturen: Etnobiologi i Sverige 1, edited by B. Pettersson, I. Svanberg, and H. Tunón pp. 90-98. Wahlström \& Widstrand, Stockholm, Sweden.

Svanberg, I. 2006a. Black Slugs (Arion ater) as Grease: A Case Study of Technical Use of Gastropods in Pre-Industrial Sweden. Journal of Ethnobiology 26:299-309. DOI:10.2993/0278-0771.

Svanberg, I. 2006b. Humlehonung, Korstroll och alamask: Etnobiologiska Essäer om Evertebrater $i$ Norden och Estland. Swedish Science Press, Uppsala, Sweden.

Svanberg, I. 2007. Human Usage of Mermaid's Glove Sponge (Isodictya palmata) on the Faroes. Journal of the Marine Biological Association of the United Kingdom 87:1773-1775. DOI:10.1017/S0025315407060766.
Svanberg, I. 2008. Jellyfish in North European Folk Biology. Svenska Landsmål och Svensket Folkliv 131:115-124.

Svanberg, I. 2017. Cuckoo Spit in Northern European Folk Biology. Yearbook of the Swedish Linnaeus Society 2016:117-121.

Svanberg, I. 2018. Common Starfish (Asterias rubens) in Nordic Folk Biology. Yearbook of the Swedish Linnaeus Society 2018:113-118.

Svanberg, I., R. Sõukand, Ł. Łuczaj, R. Kalle, O. Zyryanova, A. Dénes, N. Papp, A. Nedelcheva, D. Šeškauskaitè, I. Kołodziejska-Degórska, and V. Kolosova. 2012. Uses of Tree Saps in Northern and Eastern Parts of Europe. Acta Societatis Botanicorum Poloniae 8:343-357. DOI:10.5586/asbp.2012.036.

Tiedeken, E. J., J. C. Stout, P. C. Stevenson, and G. A. Wright. 2014. Bumblebees are Not Deterred by Ecologically Relevant Concentrations of Nectar Toxins. Journal of Experimental Biology 217:1620-1625. DOI:10.1242/jeb.097543.

Tillhagen, C-H. 1958. Folklig Läkekonst. Nordiska Museet, Stockholm, Sweden.

Ulicsni, V., I. Svanberg, and Z. Molnár. 2016. Folk Knowledge of Invertebrates in Central Europe: Folk Taxonomy, Nomenclature, Medicinal and Other Uses, Folklore, and Nature Conservation. Journal of Ethnobiology and Ethnomedicine 12:1-40. DOI:10.1186/s13002-016-0118-7.

Van Engelsdorp, D., and M. D. Meixner. 2010. A Historical Review of Managed Honey Bee Populations in Europe and the United States and the Factors that May Affect Them. Journal of Invetebrate Patholoy 103 Suppl. 1:80-95. DOI:10.1016/ j.jip.2009.06.011.

Wennberg, F. 1873. Ordbok öfver Allmogeord $i$ Helsingland. Sam. Hellström, Hudiksvall, Sweden.

Williams, I. H., P. Padjus, E. Pärn, M. Rootslane, and J. Susi. 1995. A History of Beekeeping in Estonia. Bee World 76:18-30. DOI:10.1080/0005772X.1995.11099234.

Zagrobelny, M., A. L. Dreon, T. Gomiero, G. L. Marcazzan, M. A. Glaring, B. Lindberg Møller, and M-G. Paoletti. 2009. Toxic Moths: Source of a Truly Safe Delicacy. Journal of Ethnobiology 29:64-76. DOI:10.2993/0278-0771-29.1.64. 